\title{
Assuring good food handling practices in hospitality, financial costs and employees' attitudes: A case study from Serbia
}

\author{
Dušan Borovčanin ${ }^{1}$, Nataša Kilibarda ${ }^{1 *}$
}

A b s tra c t: Foodborne diseases are a major threat in the hospitality and foodservice industry. Foodborne incidents registered away from home make up the majority of cases registered in different areas of the world. Since hotels, restaurants and other foodservice establishments are a last line of defence before the food reaches the consumer, the importance of food safety systems in these businesses is vital. Especially in hospitality, successful implementation and efficient application of the HACCP system largely depends on education and motivation of employees who manipulate food. This case study analysed the attitudes of managers and employees in charge of Food \& Beverage operations in a corporate luxury hotel in Belgrade. The study showed, on average, the positive attitude of managers and employees towards the issues of food safety and their responsibility in its assurance. Moreover, employees demonstrated a generally high level of satisfaction with their work environment and work conditions and a moderate interest in education and training related to food safety. However, although a HACCP system was documented, the documentation was not systematized and verification of the system was not conducted as planned. Finally, there was no budget defined for food safety related issues such as education and training and external consultations. It is argued that financial costs of food safety, especially those related to education and training, should not be a cause for concern for hotel managers, since evidence from this research suggests they are not significantly impacting the overall food and beverage expenses.

Keywords: food safety, good hygienic practice, hotel, cost, financial analysis.

\section{Introduction}

Food produced in hospitality significantly contributes to the overall food supply. In addition, hospitality is a labour-intensive industry, which contributes significantly to employment, local and international gross domestic product (GDP) and tourism development (UNWTO, 2011). Hospitality is understood as a service industry that provides accommodation and food and beverage (F\&B) services (Al Yousuf et al., 2015). Foodservice, however, implies activities that produce meals ready for immediate consumption either in conventional restaurants, self-service or takeaway restaurants with or without available seating (United Nations, 2008). Therefore, the food service industry, defined this way, represents over $60 \%$ of establishments serving food under the scope of the food economy, since it includes service in restaurants, bars and cafes, but also restaurants in hospitals, hotels, prisons etc. (Taylor \& Forte, 2008; Al Yousuf et al., 2015).

The occurrence of foodborne diseases in organisations serving food and beverages is not such a rare occurrence. The reason behind this fact might be due to the heterogeneity of the foodservice industry, which comprises everything from street food handlers to corporate hotels and franchised restaurants that are normally characterised by high internal safety standards (Jones et al., 2008; Al Yousuf et al., 2015). Thus, in the USA for example, for several years now, the highest number of foodborne diseases has been registered in restaurants, i.e. over half of the foodborne diseases (64\% to be precise) are registered away from home (Centers for Disease Control and Prevention (CDC), 2019). In the European Union, according to the European Food Safety Authority and European Centre for Disease Prevention and Control (EFSA \& ECDC, 2018), the latest trends show the majority of foodborne diseases are registered within households, followed immediately by those in the foodservice industry.

When it comes to food safety, it is known and confirmed that every link in the food chain holds a certain level of responsibility. Restaurants are generally perceived as the last line of defence before the

${ }^{1}$ Singidunum University, Danijelova 32, 11010 Belgrade, Republic of Serbia.

*Corresponding author: Nataša Kilibarda, nkilibarda@singidunum.ac.rs 
food reaches the consumer (Kilibarda, 2019). One of the ways to ensure food safety is through food safety systems like Hazard Analysis and Critical Control Points (HACCP). The HACCP system aims to identify potential hazards and assess where in the production process these hazards could pose a high risk for food safety, but also where and how they can be controlled (or reduced to an acceptable level or eliminated). In Serbia, according to the Food Safety Law RS 17/2019 (Serbia, 2019), all subjects involved in food production (in terms of this law, these are hospitality facilities that provide F\&B services) are obliged to establish a system for ensuring food safety in accordance with the principles of good hygiene production and practice and HACCP. In this way, both guest and hospitality organisation are assured about food safety and customers can, therefore, enjoy the quality of food and beverages (Aziz \& Dahan, 2013).

In addition, the application of the HACCP system ensures that food production is carried out as uniformly, economically and efficiently as possible, and with reduced food waste. Furthermore, the employee's awareness and competence level in food handling are also increased with HACCP. In order for the HACCP system to be implemented and enforced efficiently and effectively in a particular food service establishment, it is first necessary that the prerequisite programs of Good Manufacturing Practice (GMP) and Good Hygiene Practice (GHP) are fully introduced and implemented. Both of these systems are recognised internationally by the Codex Alimentarius Commission (Codex Alimentari$u s, 2003$ ).

With the implementation of the above-mentioned programs and compliance with general hygiene principles, adequate procedures are ensured in all food-related activities. However, when it comes to the implementation of the HACCP system in hospitality, problems are often encountered in practice. It should not be forgotten the HACCP system was developed for the needs of the USA space program and was later adopted for use in the food manufacturing industry (Taylor \& Forte, 2008). The very assumption that the system could be applied without difficulties in hospitality is not rational, since hotels are characterised by several specifics in relation to the rest of the foodservice industry. Some of the specifics are the large amount of input raw materials and final products and the wide variety of recipes, which are caused by the need to adapt to the requirements of guests or due to market competitiveness. All together, this causes an unbalanced volume of food production (that varies daily and seasonally) which is often hard to predict (Taylor, 2008; Taylor $\&$ Forte, 2008). Moreover, another problem is often the physically small manoeuvreing space for the production of several dishes simultaneously (Eves \& Dervisi, 2005; Taylor \& Forte, 2008; Garayoa et al., 2011). In addition, a further hospitality-specific issue is the simultaneous production and serving of food (Garayoa et al., 2011; Taylor \& Forte, 2008).

Small businesses in hospitality often state they experience problems related to financial and infrastructural resources when it comes to HACCP implementation (Eves \& Dervisi, 2005; Taylor \& Forte, 2008). Apart from financial and infrastructural resources, a lack of time and information related to HACCP are also mentioned problem areas (FDA, 2006; Taylor, 2008). In addition to these obstacles, inadequate space where food production takes place or obsolete equipment that affects performance were also identified as problems (Wandolo et al., 2018). However, in restaurants belonging to large hotel chains, where financial and infrastructural resources should not cause a concern, unskilled staff and the lack of training could be a weak point within the food production process that can lead to increased food safety risk (Matias et al., 2013; Casolani \& Del Signore, 2016).

Among the most common reasons for the occurrence of foodborne disease in hospitality are raw materials that come from unsafe and unchecked sources, inadequate heat treatment of food, inadequate food storage temperature, improper procedures for defrosting food, contaminated equipment, poor hygiene and/or illness of employees, and inadequate food handling by employees, which is why cross-contamination occurs (Bolton et al., 2004; Bolton et al., 2008; Adesokan et al., 2015; Jankovic et al., 2017).

The human factor is highly significant within cross-contamination in hospitality (McIntyre et al., 2013). The reason for this is because food handlers often have different levels of education, from lower to higher education, but also very different levels of skills and competences. Moreover, hospitality is characterised by a significant degree of seasonality, which often leads to high turnover rates (Panisello \& Quantick, 2001; Taylor \& Forte, 2008; Taylor, 2008; Casolani \& Del Signore, 2016), leading further and often to lower levels of training and competencies.

Although, a lack of language skills in the language in which internal training is conducted can be an obstacle to successful understanding of training and adoption of knowledge and practices in the area 
of food safety (Eves \& Dervisi, 2005), good training is still the most widespread strategy that effectively improves food safety via a vis the application of good hygiene practice (Hislop \& Shaw, 2009; Medeiros et al., 2011; Martins et al., 2012; Rossi et al., 2017; Zanin et al., 2017). Successful implementation of HACCP, but also continuous and efficient application of the HACCP system, especially in hospitality, largely depends on education and lasting motivation of employees who manipulate food. In addition, successful and on-going HACCP largely depends on individuals' awareness of the importance of education in this area and the degree of responsibility delegated to them in the process of producing safe food (Seaman \& Eves, 2006; Zanin et al., 2017).

That is why there is a significant amount of research related to the assessment of knowledge and attitudes about food safety and the application of good hygiene practice by employees in the hospitality industry (Seaman \& Eves, 2006; Ko, 2013; McIntyre et al., 2013; Adesokan et al., 2015; Rebouças et al., 2017; Barjaktarović-Labović et al., 2018; Al-Kandari et al., 2019). Because food handlers have a major role in the prevention of foodborne disease, properly managing human resources is an important step in preparing safe food for consumers (Eves \& Dervisi, 2005; Bolton et al., 2008; Rossi et al., 2017).

Top management of hotels needs to plan and allocate time and other necessary resources for education and training of employees (Cates et al., 2009; Kassa et al., 2010; Rebouças et al., 2017). It is essential that, while doing so, managers understand the activities performed by every food handler in order to achieve the ultimate goal, which is safe food (Garayoa et al., 2011). Knowledgeable managers can act proactively and with prevention, thereby reducing the potential risks of unsafe food, which are most often caused by inadequate food handling.

However, in order for these activities to be effective and efficient, managers must be qualified, competent and have appropriate knowledge in the field of food safety, which, in practice, is usually not the case. People from a technological, food safety or similar educational and professional background are not normally the majority in hospitality (Taylor \& Forte, 2008). Even managers themselves do not possess a professional education that would provide them with the appropriate competence and knowledge about jobs related to food safety, which is why they mainly rely on experience $(K o, 2013$; Rebouças et al., 2017). This is often an obstacle for the successful implementation of food safety policy.
For this reason, the question arises, to what extent, and in what way, do hotels, and especially large hotel chains, really invest in the F\&B sector itself, and how much they are really willing to allocate financial investments for internal and/or external staff training related to food safety in the F\&B sector, taking into account the specific and overall business and operations of the F\&B sector.

\section{The relative importance of food and beverage in the hotel}

The F\&B department, alongside the room sector, is among the two most important departments in the hotel business. In many countries, having a full-service restaurant is a mandatory element in the process of hotel categorisation. Nevertheless, F\&B in hotels is more often seen by hotel managers as a complementary element. The reason for this attitude lies in the fact that in most cases, the F\&B sector does not contribute significantly to the overall hotel revenue relative to the room sector (Chen \& Chang, 2012; Yeh et al., 2012).

Also, until recently, a large number of guests viewed F\&B services in hotels as partially irrelevant, primarily due to the restaurant expensiveness, and, in Serbia, given the large number of alternative, traditional restaurants that can be often found in close proximity to most hotels. In addition, several studies have shown that guests valued $\mathrm{F} \& \mathrm{~B}$ relatively poorly when compared to other criteria, such as room cleanliness, location and price, while making their purchasing decision. Therefore, many hotels have shifted their focus towards the room sector, while also shifting the form of food service towards a buffet (which has far lower operating costs) (Hemmington \& King, 2000), and even, in certain cases, completely outsourcing the $\mathrm{F} \& \mathrm{~B}$ division in order to focus on what pays the highest profits, i.e., the room sector (Hemmington \& King, 2000; Espino-Rodríguez \& Padrón-Robaina, 2004; Promsivapallop et al., 2012). Almost two decades ago, we witnessed examples of several hotel brands that even abandoned the practice of investing in their own F\&B sector, strategically re-locating their facilities and placing new ones near well-known, independent restaurants. This was the case with hotel brands such as Travelodge or Travel Inn (Hemmington \& King, 2000).

However, recent changes in the global market show signs of significant shifts regarding F\&B's importance and position in hospitality. These changes are so big that some hotel chains even see their strategic reorientation precisely in transforming the 
F\&B sector (Chesters, 2017; Ting, 2019). These shifts made by large hotel chains may seem unsubstantiated given the foregoing, but it should be borne in mind that the results from the studies above (Chesters, 2017; Ting, 2019) vary significantly with the size and type of service the hotel provides, as well as the market segment to which guests belong. Also, the fact that guests place such relatively less importance on F\&B when booking accommodation is due to the fact that $\mathrm{F} \& \mathrm{~B}$ service is something that is often implied (Albayrak \& Caber, 2015). Their position is to some point confirmed by the evidence which shows the true value of F\&B can only be seen in its absence, as evidenced by the results of a study of the operational performance of $F \& B$ and non-F\&B hotels in New York and California (Mun et al., 2019). The results of this study clearly show the significantly higher performance of full-service hotels than the limited-service hotels.

Finally, in the case of luxury hotels, the quality of F\&B and the quality of service have a significant effect on customers' loyalty. Guests who were satisfied with the food and drink at hotels showed a greater degree of readiness to stay at the same hotel, even if they chose other restaurants within the same hotel (Han \& Hyun, 2017).

\section{The financial contribution of food $\&$ beverage in a hotel: a stumbling point for good handling practices?}

Why is F\&B profitability so important and how is it related to food safety? First of all, F\&B is not the most profitable sector in a hotel. It is characterized by high labour costs, high variable costs and low profitability. The average profitability of the F\&B sector ranges between $20-30 \%$ in Europe and the Americas, while in the Middle East and Africa it can reach 40\% (Elsen, 2019a; 2019b; 2019c). This is, however, significantly lower than the profitability of the room sector, which normally ranges between $70-80 \%$, generating more than $60 \%$ of total hotel revenue on average (Elsen, 2019b, 2019c, 2019a).

On the other hand, ensuring good hygiene practices in a hotel requires significant investment in equipment, technology, staff, and staff education and training, so therefore, one should not be surprised by the manager's restrained attitude when it comes to investing in good hygiene practices. For hotel managers, profitability and cost analysis are of utmost importance in management (Singh \& Schmidgall, 2002). This is driven by the increasing expectations of investors who expect high returns on their investment (Maier, 2016). Is it then possible to invest in good hygiene practices while maintaining or increasing the profitability of the F\&B sector?

The importance of safe food and good hygiene practices in hotels is unequivocal in relation to guest safety. However, absolute food safety is unattainable, and therefore, the question arises of optimal investment in safe food and the risk of incidents resulting from inadequate practices. One incident can permanently damage a hotel's reputation and, in the long run, ruin its business reputation and business performance, not to mention the ramifications of the most serious cases of fatal illness and food poisoning that can also carry legal responsibility. For this reason, the implementation of GHP is very important for foodservice, as is the high-quality food that is necessary to earn and keep guest trust and loyalty $(K o, 2013)$.

For managers, one way to invest in food safety is to invest in safety certification. The most common concern before entering the certification process is the cost and impact on the operational efficiency of the department. So far, there are a number of contradictory studies that link certification and its impact on business results (Aba et al., 2015; Al-Refaie et al., 2012; Chatzoglou et al., 2015; Islam et al., 2016; Kusumah \& Fabianto, 2018). A recent study indicates that the introduction of quality management systems (referring to ISO 9001) and hotel certification has nothing to do with business performance, although it has a significant relationship with operating performance (Duman et al., 2019). Methodologically, however, this study did not test whether quality assurance through certification and its impact on operational performance parameters such as guest loyalty and employee satisfaction actually emerges as a mediator in the process of achieving business performance parameters such as total revenue, profitability, occupancy etc. Another study with empirical findings shows that through careful prevention, assessment and reduction of failures in $\mathrm{F} \& \mathrm{~B}$, a hotel can significantly improve its financial performance (Ramdeen et al., 2007).

When it comes to practical implementation, a recent study has indicated that food safety in a hotel depends predominantly on the will of hotel management (Wu, 2012). For this reason, our research focuses on three components: 1) to determine the level of willingness of hotel managers in Belgrade to implement good hygiene practices; 2) to determine the relative level of investment in good hygiene practice, and; 3 ) to determine the attitude of operational 
staff in F\&B (which is one of the most critical control points of the whole process) about good hygiene practices.

\section{Materials and Methods}

\section{The hotel}

For the purposes of this research, we selected a luxury hotel in Belgrade that is the most developed tourist destination according to its number of arrivals and tourism income (Ministry of Trade, Tourism and Telecommunications, 2020). The hotel operates as a part of one of the world's leading corporate chains and uses the franchise of the premium brand of that hotel chain. The hotel has a staff of 105 employees, 36 (34\%) of which are employed in the $F \& B$ sector. In addition to the kitchen, $F \& B$ runs two hotel restaurants, a lobby bar and a multifunctional banquet hall that can be divided into several units where food and drink can be served for various types of events.

The kitchen is a unique functional unit consisting of several work areas in which the technical-technological process of food preparation takes place. It fulfils all technical, technological, sanitary-hygienic and organizational-staff requirements in accordance with the current regulation (Serbia, 2016). The hotel has an established and documented HACCP system. However, the documentation is not systematized and the verification of the system is not conducted systematically and with plan. Therefore, this hotel is not HACCP certified. Also, the hotel does not have certification for either the international standard for quality management system (SRPS ISO, 2015) or food safety standard (SRPS EN ISO, 2018).

\section{Research sample and method}

A qualitative approach was applied in this research since it is a case study, and it is one of the first studies of this type performed in Serbia. After a site inspection, interviews were conducted with the manager of the F\&B sector and the kitchen head chef to determine the will and attitudes of the top executives in relation to good hygiene practices.

In order to conduct quantitative research and collect the data, a questionnaire of 10 questions with a five-point Likert-scale was created. Respondents had to answer by rounding off one of the offered choices. All respondents participated in the research willingly, and they were informed in advance about the research and that the data would be used exclusively anonymously and that they could withdraw from the research at any time without any consequences. The research was conducted in accordance with the ethical principles and code of conduct prescribed by the American Psychological Association (APA, 2017).

The questionnaire consisted of two parts. The first part consisted of questions related to the socio-demographic status of the respondents (gender, age, work experience and education).

The second part of the questionnaire consisted of 10 questions related to employees' attitudes. The questions were related to: 1) the attitude of employees on their role in the process of delivering safe food, then; 2) the number and quality of on-the-job training sessions in relation to good hygiene practice and food safety, and; 3) the satisfaction of employees with their work conditions, personal income and the equipment they use.

Finally, by rounding off one of the answers to the last question, the respondents had to decide on what was, according to their opinion, a major difficulty when it comes to the adequate implementation of good hygiene practice. Subsequently, questionnaires were distributed to all employees in the F\&B department, of which $29.4 \%$ were returned completely filled.

After data collection, in order to perform further analyses, the data were coded and transformed into a numerical matrix. Data from the first part of the survey were transformed into nominal and ordinal scales according to respondents' answers and their frequency. The Likert scale answers and results were analysed as follows: from 1 to 1.5 - very negative attitude, from 1.5 to 2,5 - moderately negative, from 2.5 to 3.5 - neutral attitude, from 3.5 to 4.5 - moderately positive, from 4.5 to 5 - very positive attitude about food safety on trips. The collected answers to the last question were grouped and expressed as a percentage frequency.

\section{Results and Discussion}

In an interview with the hotel's F\&B manager, he demonstrated a positive attitude towards food safety. His attitude could be clearly evidenced by his statement "I am aware of the importance of safe food and good hygiene practices and the role of my team in ensuring it. For this reason, several times my team and I have launched the HACCP certification initiative. Although the hotel is not certified yet, we strive to deliver quality the same way as if the hotel was certified." 
This attitude from the F\&B manager is very encouraging and important. The literature points out that a positive attitude of managers towards the implementation and enforcement of good hygiene practice can have a significant impact on its adequate application by the employees, because it has a positive effect on the transfer of knowledge, feedback of information, self-control and individual commitment to the implementation of GHP (Eves \& Dervisi, 2005; Seaman \& Eves, 2006; Ko, 2013; Casolani \& Del Signore, 2016). Employees' motivation and approval from management are also crucial for successful food safety management. Without any demonstrated commitment from management, the fact is that investing in employee training alone would not lead to improved practices, and thus, to increased food safety (Seaman \& Eves, 2006).

As the biggest obstacle to certification, the F\&B manager cited the financial costs, while in addition to costs, the head chef also cited the excessive number of lists and documentation that operationally slows the team down. The chef indicates the additional imposition of administrative duties on the members of his team, stating that "when a hotel is running with full capacities and when there is a big event staging in the hotel apart from regular guests, work in the kitchen becomes extremely demanding. Introducing additional tasks that certification might bring would further slow us down, and the speed of meal production is very important in these situations."

This attitude is not surprising (indeed, it is expected) given the specificity of food production in hospitality where a large number of different dishes is produced. The process of food production and food serving is simultaneous, and there are often changes within the menu, which are an aggravating circumstance when it comes to application and certification of the HACCP system $(K o, 2013)$. Similar attitudes were discovered in qualitative research done by Eves \& Dervisi with managers from the foodservice industry (Eves \& Dervisi, 2005). Namely, HACCP itself cannot make food safe, but its proper implementation can. In order to implement the system properly, it is necessary to remove barriers, such as for example, the perception of management and employees that HACCP means both additional and unnecessary administration that can only slow down the process.

Although young (staff were 28 years old, on average), the F\&B team had several experienced individuals who train younger staff, especially during the socialization process. Both managers demonstrated a positive attitude towards safe food training. They stated that additional training for their team would be beneficial. The main obstacle is the lack of a predefined budget for these purposes and the definite and mandatory number of training sessions that must be completed. The manager of the F\&B sector further states: "The corporation insists on other types of training such as upselling and cross-selling training, but certainly more training about food safety would be much more useful for us."

For the successful implementation and maintenance of the HACCP system and GHP, it is of great importance that there are predetermined financial resources are allocated for costs related to the monitoring and record-keeping, staff training, costs of corrective actions when the critical limit is exceeded and costs of consultations that may be required. Often, the need to increase sales in the F\&B sector and generate higher revenues can push aside training and improving knowledge to refresh good hygienic practice (Panisello \& Quantick, 2001). In the worst-case scenario, this can cost much more, as lack of training can be a significant risk in hospitality when it comes to the occurrence of foodborne disease, as mentioned above.

Since this is a new and luxurious hotel, care had been taken to meet all infrastructure requirements and to reduce the risk of cross-contamination to a minimum, which is one of the main prerequisites for adequate and proper implementation of GHP (da Cunha et al., 2013; Zanin et al., 2017). As it is a high-end luxury hotel, the equipment in the hotel is at a satisfactory level, while investment in the equipment, in addition to the on-going maintenance, is made every two years. The hotel possesses a licence for software aimed to control the cost of F\&B materials, i.e. Materials Control, one of the world's leading Oracle solutions for this purpose. However, there is no software system for temperature monitoring that provides cold chain information, although there are thermometers on every device in the kitchen that are manually monitored and recorded. Also, the hotel does not have any software that monitors inventory expiry dates. However, investing in a system that would automatically and continuously track the temperatures of refrigeration devices could significantly save time for employees, especially since $50 \%$ of the respondents, when asked what they consider to be the biggest obstacle to doing business under the GHP, stated too many responsibilities per employee (Figure 1). On the other hand, software that monitors products' expiry 


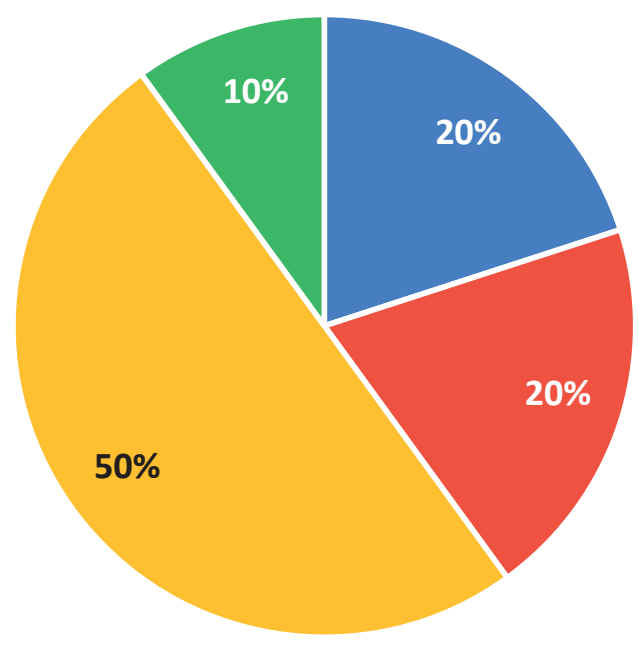

- Insufficient amount of training in good hygiene practice

- Staff incompetence

Too many duties for one position

Too much documentation

Figure 1. Major difficulties reported by employees regarding adequate implementation of good hygiene practice

dates could significantly save employees' time in terms of inventory control necessary to the first-in first-out principle. This could positively affect total costs in F\&B, with less waste of expired foods/products. This would enhance the food safety management and management of food waste (Kilibarda et al., 2019; Kilibarda, 2019).

The demographic structure of the respondents was fairly balanced in relation to gender. Female respondents made up $60 \%$ of our survey respondents, while male respondents comprised $40 \%$ of the sample. The average age of respondents in the F\&B department was 28.2 years, meaning this is a relatively young team. The average number of years of experience in the $\mathrm{F} \& \mathrm{~B}$ business from our respondents was 6.4 years, which was clearly related to the age structure of the respondents. When it comes to educational level, this was balanced between respondents having attended high school and having a bachelor's degree (60:40 in favour of high school), which is in line with the usual education level in hospitality in Serbia (Table 1).

To ensure food safety in the F\&B sector in hotels, it is fundamental to establish and maintain good hygienic practice (Martins et al., 2012; Serafim et al., 2018). Training of food handling employees is the most widespread strategy that effectively improves food safety (Hislop \& Shaw, 2009; Medeiros et al., 2011; Martins et al., 2012; Soares et al., 2012; da Cunha et al., 2013; Zanin et al., 2017), given that the majority of foodborne diseases in hospitality occur as a result of inadequate food handling (Zanin et al., 2017; Barjaktarović-Labović et al., 2018). However, the training itself can lead to improvements in the application of good hygiene practice only if the transferred knowledge leads to changes in practice (daily activities) or attitudes of employees in the workplace (Seaman \& Eves, 2006; Zanin et al., 2017). Two studies have shown no positive correlation between employees' knowledge and their daily practice (Soares et al., 2012; da Cunha et al., 2013). The reason for this may be that the proper application of adequate practice in routine work depends on the motivation of employees, their awareness of their job importance and the level of responsibility they have in the process of food production, regardless of their level of knowledge (Seaman \& Eves, 2006; Zanin et al., 2017).

Our research aimed to determine the attitudes of employees in relation to responsibilities and training related to food safety. Attitude is a crucial factor influencing employee behaviour and practice, since a positive attitude can reduce the incidence of foodborne disease. Attitude represents a link between knowledge and practice (Ko, 2013; Manning, 2018), i.e., employees who have more knowledge are more likely to apply it in practice if they have a positive attitude and vice versa (Zanin et al., 2017; Al-Kandari et al., 2019), the training of employees, and their gaining a higher level of competence, will not lead to improved practice if the attitude of employees towards training is negative (Bolton et al., 2008).

In our research, the answers to the first three questions, which were related to the employee's attitude towards responsibility for food safety in the

Table 1. Employees' characteristics (\% of respondents)

\begin{tabular}{ll|ll|ll|ll}
\hline \multicolumn{2}{c|}{ Gender } & \multicolumn{2}{c|}{ Age } & \multicolumn{2}{c|}{ Education } & \multicolumn{2}{c}{ Work experience } \\
\hline Female & 70 & $<25$ years & 50 & High school education & 60 & $<10$ years & 70 \\
Male & 30 & $>26$ years & 50 & Higher education & 40 & $>10$ years & 30 \\
\hline
\end{tabular}


Table 2. Questionnaire administered to ascertain employees' attitudes towards food safety and the average score attained

\begin{tabular}{lc}
\hline Questions & Average score \\
\hline $\begin{array}{l}\text { 1. Food handling employees have a significant level of responsibility in terms of food } \\
\text { safety }\end{array}$ & 4.6 \\
2. Education and training of employees related to good hygiene practice are important & 4.7 \\
activities of employees in the F\&B sector & \\
3. Education and training I had related to GHP impacted significantly and enabled me \\
to understand the importance of GHP in food safety assurance \\
$\begin{array}{l}\text { 4. Education and training I had on GHP impacted significantly my personal sense of } \\
\text { responsibility on workplace }\end{array}$ \\
$\begin{array}{l}\text { 5. I consider that additional education and training on GHP would change my } \\
\text { behaviour and daily routine }\end{array}$ \\
$\begin{array}{l}\text { 6. I consider that additional education and training are necessary for F\&B employees } \\
\text { 7. I am satisfied with the number of education and training sessions on GHP provided } \\
\text { by my employer }\end{array}$ \\
$\begin{array}{l}\text { 8. I am satisfied with the quality of education and training on GHP received so far } \\
\text { from my employer }\end{array}$ \\
$\begin{array}{l}\text { 9. I am satisfied with my personal income } \\
\text { 10. I am satisfied with my work uniform and protective equipment (quantity and } \\
\text { quality) provided by my employer }\end{array}$ \\
\hline
\end{tabular}

workplace and towards the training they received on the application of good hygiene practice, demonstrated high average scores $(\mathrm{Q} 1=4.6, \mathrm{Q} 2=4.7$, $\mathrm{Q} 3=4.6)$ (Table 2). It can be argued that the F\&B staff are aware of their responsibilities in the workplace when it comes to food safety and that they have a very positive attitude towards the training they had regarding the application of good hygiene practice. Ko found similar results in his surveys of the attitudes of food handlers in restaurants (2013). This attitude of the respondents is very satisfactory and encouraging given the recommendations by the Codex Alimentarius (2003). The attitudes of employees who do not consider training important and useful are considered especially risky for food safety (Zanin et al., 2017).

The average score from the respondents about the degree to which training enabled them to consider the degree and importance of personal responsibility in the workplace when it comes to food safety is fairly positive $(\mathrm{Q} 4=4.1)$ (Table 2$)$.

The reason for the fact that a distinctly positive attitude has not been established as in the previous three questions could be that the choice of formal education in the hospitality profession already affects the development and perception of the importance of this type of responsibility in the workplace. It is also interesting that moderately positive attitudes were established regarding the statement that attending more training on GHP would improve behaviour in the workplace when it comes to its implementation $(\mathrm{Q} 5=3.8)$ and to the statement that employees need more training on applying GHP $(\mathrm{Q} 6=4.0)$ (Table 2).

Although employees evaluate and consider their responsibility in the workplace and the training they have attended very positively, they expressed only a moderately positive attitude towards attending a larger number of training sessions as well as the usefulness of those sessions. This attitude could be improved primarily through detailed planning and design of training, because the success of training largely depends on the method of implementation. Employees should be provided with training containing less theory and more practice, which often results in higher effectiveness (Medeiros et al., 2011; Zanin et al., 2017).

When planning training for employees, it is necessary to take care that training sessions do not last for too long, as this can create resistance among employees. Training should be, rather, practical, short-lasting, periodic and relevant (Soares et al., 2012; Adesokan et al., 2015).

Analysing the responses of the F\&B employees, a moderately positive attitude towards the number and quality of training sessions on the application 
of GHP provided by the hotel for employees was determined (Q7=4.1, Q8=4.0) (Table 2). In the hotel selected for this case study, based on information received from the manager, training on the application of GHP is conducted only for newcomers (recently hired staff). However, for employees in the F\&B sector, continuous and/or periodic training on the application of good hygiene practice or periodic refresher training courses are not organised ( $\mathrm{Co}-$ dex Alimentarius, 2003). These types of training are of essential importance from the aspect of updating knowledge and maintaining motivation levels (Casolani \& Del Signore, 2016).

Despite the moderately positive average ratings of employee satisfaction when it came to the quality and number of training sessions, it can be concluded that in fact, these moderately high average ratings are cause for potential concern. Why?

The fact is that each F\&B staff member at the hotel has had only one training session on the application of GHP since they were hired. It was previously pointed out that trained staff helps guarantee food safety, that training is an urgent need, and that the frequency of errors during work increases with the lack of training (Clayton \& Griffith, 2004). Furthermore, the knowledge, once acquired, declines over time (McIntyre et al., 2013). According to Soares et al. (2012), training is an integral part of creating a positive culture of food safety, and must be conducted periodically to reduce the risk of foodborne disease. Our results suggest it is necessary to conduct further research to determine the level of employees' knowledge about food safety and the adequacy of their applying GHP during routine work.

In general, it could be argued that employee satisfaction with work conditions and personal income was positive $(\mathrm{Q} 9=4.4)$ (Table 2$)$. A moderately positive attitude of employees was also determined when it came to employee satisfaction with work uniforms and equipment $(\mathrm{Q} 10=3.8)$ (Table 2). Clayton \& Griffith (2004) point out that the attitudes of F\&B employees are in fact determined and positively correlated with resources and infrastructure of the hotel. Also, employee satisfaction, both in terms of earnings and work conditions, affects the consistent application of GHP, and thus, increased satisfaction reduces the risk of unsafe food (Rebouças et al., 2017; Zanin et al., 2017).

The hotel used for this research is in the top 10 hotels in Serbia measured by the level of sales, according to the Business Registers Agency of Serbia. The profitability of the $\mathrm{F} \& \mathrm{~B}$ sector in the hotel is at the level of $30 \%$, which is in line with the European average and can be considered as a positive indicator of the business approach.

Nonetheless, results from Table 3 show the hotel used for this case study had a financial struggle to achieve an operating profit during the last five years. However, its F\&B sector performs well, as it achieves a stable operating profit. It is reasonable to understand that adding additional costs to the operation in a situation when hotels struggle to achieve and maintain profit might be inconceivable for hotel managers. Nevertheless, additional costs of education and training

Table 3. Financial results of the hotel and cost of education and training in food safety

\begin{tabular}{lccccccc}
\hline & $\mathbf{2 0 1 4}$ & $\mathbf{2 0 1 5}$ & $\mathbf{2 0 1 6}$ & $\mathbf{2 0 1 7}$ & $\mathbf{2 0 1 8}$ & $\begin{array}{c}\text { Sum of last } \\
\text { 5 years }\end{array}$ & $\begin{array}{c}\text { 5 year } \\
\text { average }\end{array}$ \\
\hline Total revenue $(€)^{*}$ & 99,696 & $2,528,388$ & $4,559,476$ & $5,997,593$ & $6,016,823$ & $19,201,976$ & $3,840,395$ \\
Total expenses $(€)^{*}$ & $2,232,984$ & $4,932,716$ & $5,460,626$ & $6,936,307$ & $5,685,192$ & $25,247,825$ & $5,049,565$ \\
F\&B revenue $(€)^{* *}$ & 744,328 & $1,644,239$ & $1,820,209$ & $2,312,102$ & $1,895,064$ & $8,415,942$ & $1,683,188$ \\
F\&B expanses $(€)^{* *}$ & 521,030 & $1,150,967$ & $1,274,146$ & $1,618,472$ & $1,326,545$ & $5,891,159$ & $1,178,232$ \\
F\&B operating profit $(€)^{* *}$ & 223,298 & 493,272 & 546,063 & 693,631 & 568,519 & $2,524,783$ & 504,957 \\
$\begin{array}{l}\text { Total cost of education and training } \\
\text { related to food safety }(€)^{* *}\end{array}$ & 2,250 & 2,250 & 2,250 & 2,250 & 2,250 & 11,250 & 2,250 \\
$\begin{array}{l}\text { Cost of education and training in } \\
\text { total expanses (\%) }\end{array}$ & 0.101 & 0.046 & 0.041 & 0.032 & 0.040 & & 0.052 \\
$\begin{array}{l}\text { Cost of education and training in } \\
\text { total revenue (\%) }\end{array}$ & 2.257 & 0.089 & 0.049 & 0.038 & 0.037 & & 0.494 \\
$\begin{array}{l}\text { Cost of education and training in } \\
\text { F\&B expenses (\%) }\end{array}$ & 0.432 & 0.195 & 0.177 & 0.139 & 0.170 & & 0.223 \\
$\begin{array}{l}\text { Ratio of cost of education and } \\
\text { training to F\&B profit }\end{array}$ & 1.008 & 0.456 & 0.412 & 0.324 & 0.396 & & 0.519 \\
\hline
\end{tabular}

Legend: *According to the Business Registers Agency of Serbia; ${ }^{* *}$ According to data obtained 
related to food safety would increase the F\&B total expenses by less than $0.5 \%$ and would additionally assure the safety and quality of the service provided (Table 3 ).

On the other hand, excellent work conditions prevail at this hotel. This is confirmed by the average employee rating, which averaged 4.4 on a scale of 1-5 (Table 2). The average gross monthly earnings in the F\&B sector at this hotel are net 75,546.75 $\mathrm{RSD}$, which is higher than the national average and the average in the hospitality industry (Statistical Office of the Republic of Serbia, 2019).

We see this as an example of good practice, because hospitality is known to be distinguished by poor work conditions for employees (Baum, 2015). For this reason, we see investment in employees, their income, their on-the-job training and the good work conditions as a way to ensure greater hotel profitability, as shown by the results of previous studies (Yee et al., 2008; Chi \& Gursoy, 2009). This is in line with what previous studies have already shown, i.e., satisfied employees in a hotel feel enthusiastic and inspired by their job, so tend to provide better service quality to customers (Kong et al., 2010), and content employees also tend to be more intent on staying in the company (Chiang et al., 2008). This is extremely important in hospitality, as it records high employee turnover rates across the industry. There are estimates that the average turnover of frontline employees in a year in hospitality fluctuates around $65 \%$ (Myers, 2005). Low incomes and high employee turnover rates are negatively correlated with the efficiency of training and adequate adoption of practices, which can negatively affect food safety (Seaman \& Eves, 2006; Garayoa et al., 2011; Casolani \& Del Signore, 2016; Zanin et al., 2017). In this study, this was not the case, and the high satisfaction level of employees was largely related to their personal incomes, followed by the excellent work conditions.

\section{Conclusion}

Lack of employees' motivation is often identified as one of the barriers to successful GHP and HACCP implementation. In this case study, a high level of employees' satisfaction was identified, which was explained by several factors, primarily personal income, and the work environment and conditions. It is clear that, in addition to the positive attitude from the management, this is also reflected in the positive attitude of the employees and their evaluations of their own responsibilities for food safety. However, the facts that the documentation of the HACCP system is not systematized and the verification of the system is not planned clearly indicate the lack of training, primarily of the management of the $\mathrm{F} \& \mathrm{~B}$ sector.

Additionally, worrying are the lack of available, dedicated training funds in line with the lack of training for all F\&B employees. Apart from the initial financial investments (infrastructure), and current investments dedicated to the costs of equipment maintenance and monitoring of equipment performance and personal income, there are no other investments. These would refer to consulting services and external training services, which are obviously necessary for more successful $\mathrm{F} \& \mathrm{~B}$ operations in terms of food safety

This should be underlined, since evidence from our research suggest that these costs (costs for external training and consulting services related to food safety) would amount to less than $0.5 \%$ of the F\&B sector's total costs, on average, for the last 5 years of operation. Bearing in mind the importance and impact that food safety has on hospitality, the real financial costs of proper HACCP implementation and food safety excellence should not be a cause for concern.

The limitations of this research are related to the fact this is a case study, i.e., the research was conducted in only one hotel. Therefore, it is necessary to determine the attitudes in a broader sample of employees from the hospitality industry. Further research should determine the degree of employees' food safety knowledge and the degree to which they implement their knowledge in daily practice. Finally, employees' knowledge, attitudes and implementation should be studied in relation to factors such as job satisfaction, work environment and personal income. It is of great importance to further expand similar research to other business operating in the hospitality industry, especially small businesses, where very few financial resources are normally allocated for food safety. 


\section{Obezbeđenje dobre higijenske prakse u ugostiteljstvu, finansijski troškovi i stavovi zaposlenih. Studija slučaja iz Srbije}

\section{Dušan Borovčanin, Nataša Kilibarda}

A p s t r a k t: Bolesti prenosive hranom predstavljaju značajan razlog za zabrinutost u sektoru ugostiteljstva, kao i u svim subjektima koji obavljaju delatnost usluge hrane i pića. Razlog tome je što se poslednjih godina najveći broj bolesti prenosivih hranom, registruje prilikom konzumacije hrane van kuće, u različitim delovima sveta. Kako hoteli, restorani i drugi subjekti koji posluju hranom predstavljaju poslednju liniju odbrane hrane pre nego što ona dođe do potrošača, sistemi bezbednosti hrane implementirani u svim ovim subjektima su od velike važnosti za osiguranje bezbednosti hrane. Poznato je da naročito u ugostiteljstvu, uspešna implementacija kao i efikasna primena HACCP sistema, najviše zavisi od stepena obučenosti i motivisanosti osoblja koje rukuje hranom. Ova studija slučaja imala je za cilj da analizira stavove menadžera i zaposlenih u sektoru hrane i pića u jednom luksuznom, korporacijskom hotelu u Beogradu. Rezultati studije pokazali su da menadžeri i zaposleni u proseku imaju pozitivan stav prema bezbednosti hrane i odgovornostima koje imaju kada je reč o bezbednosti hrane na radnom mestu. Takođe, zaposleni su pokazali visok stepen zadovoljstva uslovima rada i okruženja, ali i umereno izraženo interesovanje za obuke i treninge koji se tiču bezbednosti hrane. Međutim, u ovom hotelu HACCP sistem je dokumentovan, ali dokumentacija nije sistematizovana, a provera efikasnosti sistema se ne izvodi planski. Dodatno, utvrđeno je i da ne postoji jasno opredeljen budžet za aktivnosti koje se odnose na osiguranje bezbednosti hrane, kao što su na primer, obuke i treninzi osoblja, kao i eksterne konsultantske usluge. Zaključeno je da finansijski troškovi koji bi se odnosili na osiguranje bezbednosti hrane, posebno oni koji se odnose na edukacije i treninge zaposlenih, ne bi trebalo da predstavljaju dodatno opterećenje za menadžere, budući da rezultati istraživanja ukazuju na to da oni ne utiču značajno na ukupne troškove sektora hrane i pića hotela.

Ključne reči: bezbednost hrane, dobra higijenska praksa, hotel, troškovi, finansijska analiza.

Disclosure statement: No potential conflict of interest was reported by the authors.

\section{References}

Aba, E. K., Badar, M. A. \& Hayden, M. A. (2015). Impact of ISO 9001 certification on firms financial operating performance. International Journal of Quality \& Reliability Management, 33(1), 78-89. https://doi.org/10.1108/ IJQRM-02-2014-0021

Adesokan, H. K., Akinseye, V. O. \& Adesokan, G. A. (2015). Food safety training is associated with improved knowledge and behaviours among foodservice establishments' workers. International Journal of Food Science, 1-8. https://doi.org/10.1155/2015/328761

Al Yousuf, M., Taylor, E. \& Taylor, J. (2015). Developing a government strategy to meet international standards of food safety across the hospitality industry. Worldwide Hospitality and Tourism Themes, 7(1), 4-16. https://doi. org/10.1108/WHATT-12-2014-0037

Albayrak, T. \& Caber, M. (2015). Prioritisation of the hotel attributes according to their influence on satisfaction: A comparison of two techniques. Tourism Management, 46, 43-50. https://doi.org/10.1016/j.tourman.2014.06.009

Al-Kandari, D., Al-abdeen, J. \& Sidhu, J. (2019). Food safety knowledge, attitudes and practices of food handlers in restaurants in Kuwait. Food Control, 103, 103-110. https:// doi.org/10.1016/j.foodcont.2019.03.040

Al-Refaie, A., Ghnaimatb, O. \& Li, M. H. (2012). Effects of ISO 9001 Certification and KAAE on Performance of Jordanian Firms. Jordan Journal of Mechanical and Industrial Engineering, 121.

APA (2017). Ethical principles of psychologists and code of conduct. https://www.apa.org/ethics/code/
Aziz, S. A. A. \& Dahan, H. M. (2013). Food handlers' attitude towards safe food handling in school canteens. Procedia - Social and Behavioral Sciences, 105, 220-228. https:// doi.org/10.1016/j.sbspro.2013.11.023

Barjaktarović-Labović, S., Mugoša, B., Andrejević, V., Banjari, I., Jovićević, L., Djurović, D., Martinović, A. \& Radojlović, J. (2018). Food hygiene awareness and practices before and after intervention in food services in Montenegro. Food Control, 85, 466-471. https://doi. org/10.1016/j.foodcont.2017.10.032

Bolton, D. J., Maunsell, B. \& Irlanda, the National Food Centre \& European Union Risk Analysis Information Network. (2004). Guidelines for food safety control in European restaurants. Teagasc: The National Food Centre.

Bolton, D. J., Meally, A., Blair, I. S., McDowell, D. A. \& Cowan, C. (2008). Food safety knowledge of head chefs and catering managers in Ireland. Food Control, 19(3), 291300. https://doi.org/10.1016/j.foodcont.2007.04.006

Casolani, N. \& Del Signore, A. (2016). Managers' opinions of factors influencing HACCP applications in Italian hotel/restaurant/café (HoReCa) sector. British Food Journal, 118(5), 1195-1207. https://doi.org/10.1108/BFJ-09-2015-0312

Cates, S. C., Muth, M. K., Karns, S. A., Penne, M. A., Stone, C. N., Harrison, J. E. \& Radke, V. J. (2009). Certified Kitchen Managers: Do They Improve Restaurant Inspection Outcomes? Journal of Food Protection, 72(2), 384-391. https://doi.org/10.4315/0362-028X-72.2.384

Centers for Disease Control and Prevention (CDC) (2019). Surveillance for Foodborne Disease Outbreaks, United 
States, 2017, Annual Report. Atlanta, Georgia: U.S. Department of Health and Human Services, CDC

Chatzoglou, P., Chatzoudes, D. \& Kipraios, N. (2015). The impact of ISO 9000 certification on firms' financial performance. International Journal of Operations \& Production Management, 35(1), 145-174. https://doi. org/10.1108/IJOPM-07-2012-0387

Chen, C.-M. \& Chang, K.-L. (2012). Diversification strategy and financial performance in the Taiwanese hotel industry. International Journal of Hospitality Management, 31(3), 1030-1032. https://doi.org/10.1016/j.ijhm.2011.10.003

Chesters, C. (2017). The Business: Redefining Accor's F\&B strategy. Catering News. https://www.hotelnewsme.com/ catering-news-me/business-redefining-accors-fb-strategy!

Chi, C. G. \& Gursoy, D. (2009). Employee satisfaction, customer satisfaction, and financial performance: An empirical examination. International Journal of Hospitality Management, 28(2), 245-253. https://doi.org/10.1016/j.ijhm.2008.08.003

Clayton, D. A. \& Griffith, C. J. (2004). Observation of food safety practices in catering using notational analysis. British Food Journal, 106(3), 211-227. https://doi. org/10.1108/00070700410528790

Codex Alimentarius (2003). Recommended International Code of Practice - General Principles of Food Hygiene CAC/ RCP 1-1969, Rev. 4-2003.

da Cunha, D. T., Fiorotti, R. M., Baldasso, J. G., de Sousa, M., Fontanezi, N. M., Caivano, S., Stedefeldt, E., de Rosso, V. V. \& Camargo, M. C. R. (2013). Improvement of food safety in school meal service during a long-term intervention period: A strategy based on the knowledge, attitude and practice triad. Food Control, 34(2), 662-667. https://doi.org/10.1016/j.foodcont.2013.06.003

Duman, F., Ozer, O., Koseoglu, M. A., Altin, M. \& Okumus, F. (2019). Does quality standards certification truly matter on operational and business performances of firms? Evidence from resort hotels. European Journal of Tourism Research, 23, 142-155.

EFSA and ECDC (2018). The European Union summary report on trendsand sources ofzoonoses, zoonoticagentsandfood-borne outbreaks in 2017. EFSA Journal 2018;16(12):5500, 262 pp. https://doi.org/10.2903/j.efsa.2018.5500

Elsen, D. (2019a). European Annual Hotel Performance Tracker 2019 [Year report]. Hotstats: Hospitality Intelligence. https://www.hotstats.com/hubfs/Research\%20pdf/Profit\%20Matters\%20-\%20MENA_Annual_Hotel_Performance_Tracker_2019.pdf?hsCtaTracking $=\mathrm{f} 42 \mathrm{a}$ 1b15375 f-49b6-9df 2 -e0e38afe 573c\% 7 C9f 21 fdbc-45814bd2-ba78-0a9dabb1ea17

Elsen, D. (2019b). MENA Annual Hotel Performance Tracker 2019 [Year report]. Hotstats:Hospitality Intelligence. https://www.hotstats.com/hubfs/Research\%20pdf/Profit\%20Matters\%20-\%20MENA_Annual_Hotel_Performance_Tracker_2019.pdf?hsCtaTracking $=\mathrm{f} 4 \overline{2} \mathrm{a}$ 1b15$375 \mathrm{f}-49 \mathrm{~b} 6-9 \mathrm{df} 2-\mathrm{e} 0 \mathrm{e} 38 \mathrm{afe} 573 \mathrm{c} \% 7 \mathrm{C} 9 \mathrm{f} 21 \mathrm{fdbc}-4581-$ 4bd2-ba78-0a9dabb1ea17

Elsen, D. (2019c). US Annual Hotel Performance Tracker 2019 [Year report]. Hotstats:Hospitality Intelligence. https:// www.hotstats.com/hubfs/Research $\% 20$ pdf/Profit $\% 20$ Matters\%20-\%20MENA_Annual_Hotel_Performance Tracker 2019.pdf?hsCtaTracking=f42a1b15-375f-49b69df2-e0e38afe573c\%7C9f21 fdbc-4581-4bd2-ba78-0a9dabblea17

Espino-Rodríguez, T. F. \& Padrón-Robaina, V. (2004). Outsourcing and its impact on operational objectives and performance: A study of hotels in the Canary Islands.
International Journal of Hospitality Management, 23(3), 287-306. https://doi.org/10.1016/j.ijhm.2003.11.004

Eves, A. \& Dervisi, P. (2005). Experiences of the implementation and operation of hazard analysis critical control points in the food service sector. International Journal of Hospitality Management, 24(1), 3-19. https://doi. org/10.1016/j.ijhm.2004.04.005

Garayoa, R., Vitas, A. I., Díez-Leturia, M. \& García-Jalón, I. (2011). Food safety and the contract catering companies: Food handlers, facilities and HACCP evaluation. Food Control, 22(12), 2006-2012. https://doi.org/10.1016/j. foodcont.2011.05.021

Han, H. \& Hyun, S. S. (2017). Impact of hotel-restaurant image and quality of physical-environment, service, and food on satisfaction and intention. International Journal of Hospitality Management, 63, 82-92. https://doi.org/10.1016/j. ijhm.2017.03.006

Hemmington, N. \& King, C. (2000). Key dimensions of outsourcing hotel food and beverage services. International Journal of Contemporary Hospitality Management, 12(4), 256-261. https://doi.org/10.1108/09596110010330831

Hislop, N. \& Shaw, K. (2009). Food safety knowledge retention study. Journal of Food Protection, 72(2), 431-435. https://doi.org/10.4315/0362-028X-72.2.431

Islam, M. M., Habes, E., Karim, A. \& Agil, S. O. bin S. (2016). Quality certification and company performance - the newly developed country experience. Journal of Business Economics and Management, 17(4), 628-644. https://doi.org/10.3846/16111699.2015.1110712

Jankovic, V., Popov Raljic, J., Djordjevic, V. (2017). Public protection - reliable allergen risk management. The 59th International Meat Industry Conference MEATCON2017, IOP Conference Series: Earth and Environmental Science conferenceseries.iop.org/ees Volume 85.

Jones, S. L., Parry, S. M., O'Brien, S. J. \& Palmer, S. R. (2008). Operational practices associated with foodborne disease outbreaks in the catering industry in England and Wales. Journal of Food Protection, 71(8), 1659-1665. https://doi.org/10.4315/0362-028X-71.8.1659

Kassa, H., Silverman, G. S. \& Baroudi, K. (2010). Effect of a Manager Training and Certification Program on Food Safety and Hygiene in Food Service Operations. Environmental Health Insights, 4, EHI.S4717. https://doi. org/10.4137/EHI.S4717

Kilibarda, N. (2019). Food Safety and Waste in Hospitality. In W. Leal Filho, A. M. Azul, L. Brandli, P. G. Özuyar \& T. Wall (Eds.), Zero Hunger (pp. 1-10). Springer International Publishing. https://doi.org/10.1007/978-3-319-69626-3_107-1

Kilibarda, N., Djokovic, F. \& Suzic, R. (2019). Food waste management - reducing and managing food waste in hospitality. Meat Technology, 60(2), 134-142. https://doi. org/10.18485/meattech.2019.60.2.8

Ko, W.-H. (2013). The relationship among food safety knowledge, attitudes and self-reported HACCP practices in restaurant employees. Food Control, 29(1), 192-197. https:// doi.org/10.1016/j.foodcont.2012.05.076

Kusumah, L. H. \& Fabianto, Y. S. (2018). The differences in the financial performance of manufacturing companies in Indonesia before and after ISO 9000 implementation. Total Quality Management \& Business Excellence, 29(7-8), 941-957. https://doi.org/10.1080/14783363.2016.1237285

Maier, T. A. (2016). Convention hotel food and beverage operating efficiency profile. Journal of Foodservice Business Research, 19(5), 514-524. https://doi.org/10.1080/15378 020.2016 .1189751 
Manning, L. (2018). The value of food safety culture to the hospitality industry. Worldwide Hospitality and Tourism Themes, 10(3), 284-296. https://doi.org/10.1108/ WHATT-02-2018-0008

Martins, R. B., Hogg, T. \& Otero, J. G. (2012). Food handlers' knowledge on food hygiene: The case of a catering company in Portugal. Food Control, 23(1), 184-190. https:// doi.org/10.1016/j.foodcont.2011.07.008

Matias, J. C. de O., Fonseca, J. M. J., Barata, I. G. \& Brojo, F. M. R. P. (2013). HACCP and OHS: Can each one help improve the other in the catering sector? Food Control, 30(1), 240-250. https://doi.org/10.1016/j.foodcont.2012.06.030

McIntyre, L., Vallaster, L., Wilcott, L., Henderson, S. B. \& Kosatsky, T. (2013). Evaluation of food safety knowledge, attitudes and self-reported hand washing practices in FOODSAFE trained and untrained food handlers in British Columbia, Canada. Food Control, 30(1), 150-156. https://doi.org/10.1016/j.foodcont.2012.06.034

Medeiros, C. O., Cavalli, S. B., Salay, E. \& Proença, R. P. C. (2011). Assessment of the methodological strategies adopted by food safety training programmes for food service workers: A systematic review. Food Control, 22(8), 11361144. https://doi.org/10.1016/j.foodcont.2011.02.008

Ministry of Trade, Tourism and Telecommunications. (2020). Ministry of Trade, Tourism and Telecommunications. https://mtt.gov.rs/en/

Mun, S. G., Woo, L. \& Paek, S. (2019). How important is F\&B operation in the hotel industry? Empirical evidence in the U.S. market. Tourism Management, 75, 156-168. https:// doi.org/10.1016/j.tourman.2019.03.010

Panisello, P. J. \& Quantick, P. C. (2001). Technical barriers to Hazard Analysis Critical Control Point (HACCP). Food Control, 12(3), 165-173. https://doi.org/10.1016/S09567135(00)00035-9

Promsivapallop, P., Jones, P. \& Roper, A. (2012). Factors influencing hotel outsourcing decisions in Thailand: Modifications to the transaction cost economics approach. Journal of Hospitality \& Tourism Research. https://doi. org/10.1177/1096348012461546

Ramdeen, C., Santos, J. \& Kyung Chatfield, H. (2007). Measuring the cost of quality in a hotel restaurant operation. International Journal of Contemporary Hospitality Management, 19(4), 286-295. https://doi. org/10.1108/09596110710747625

Rebouças, L. T., Santiago, L. B., Martins, L. S., Rios Menezes, A. C., Araújo, M. da P. N. \& Almeida, R. C. de C. (2017). Food safety knowledge and practices of food handlers, head chefs and managers in hotels' restaurants of Salvador, Brazil. Food Control, 73, 372-381. https://doi. org/10.1016/j.foodcont.2016.08.026

Rossi, M. de S. C., Stedefeldt, E., da Cunha, D. T. \& de Rosso, V. V. (2017). Food safety knowledge, optimistic bias and risk perception among food handlers in institutional food services. Food Control, 73, 681-688. https://doi. org/10.1016/j.foodcont.2016.09.016

Seaman, P. \& Eves, A. (2006). The management of food safety The role of food hygiene training in the UK service sector. International Journal of Hospitality Management, 25(2), 278-296. https://doi.org/10.1016/j.ijhm.2005.04.004

Serbia (2019). Food Safety Law. Official Gazette of the Republic of Serbia, No. 17/19
Serbia (2016). Regulation on the conditions and types of hospitality activities, the manner of providing hospitality services, classification of hospitality establishments and the minimum technical conditions for arranging and equipping hospitality facilities. Official Gazette of the Republic of Serbia, No. 58/2016

Singh, A. J. \& Schmidgall, R. S. (2002). Analysis of financial ratios commonly used by US lodging financial executives. Journal of Retail \& Leisure Property, 2(3), 201213. https://doi.org/10.1057/palgrave.rlp.5090210

Soares, L. S., Almeida, R. C. C., Cerqueira, E. S., Carvalho, J. S. \& Nunes, I. L. (2012). Knowledge, attitudes and practices in food safety and the presence of coagulase-positive staphylococci on hands of food handlers in the schools of Camaçari, Brazil. Food Control, 27(1), 206-213. https://doi.org/10.1016/j.foodcont.2012.03.016

SRPS ISO (2015). 9001:2015. Quality management systems Requirements.

SRPS EN ISO (2018). 22000:2018. Food safety management systems - Requirements for any organization in the food chain

Statistical Office of the Republic of Serbia. (2019) Yearly report on average salaries of employees, ISSN 0353-9555

Taylor, E. (2008). HACCP for the hospitality industry: History in the making. International Journal of Contemporary Hospitality Management, 20(5), 480-493. https://doi. org/10.1108/09596110810881427

Taylor, J. \& Forte, J. (2008). HACCP for the hospitality industry: The chefs' perspective. International Journal of Contemporary Hospitality Management, 20(5), 494-507. https://doi.org/10.1108/09596110810881436

Taylor, J. (2008). A new method of HACCP for hospitality: Changing behaviour and proving success. International Journal of Contemporary Hospitality Management, 20(5), 542-560. https://doi.org/10.1108/09596110820881454

Ting, D. (2019, March 29). Marriott needs to revamp its dining strategy - and knows it. Yahoo Finance. https://finance.yahoo.com/news/marriott-knows-needs-restaurant-bar-110028544.html

United Nations (2008). International Standard Indust rial Classification of All Economic Activities. ST/ESA/STAT/ SER.M/4/Rev.4, New York, 2008

UNWTO. (2011). Tourism towards 2030/Global overview (p. 49). UNWTO.

Wu, S. L. (2012). Factors influencing the implementation of food safety control systems in Taiwanese international tourist hotels. Food Control, 28(2), 265-272. https://doi. org/10.1016/j.foodcont.2012.05.038

Yee, R. W. Y., Yeung, A. C. L. \& Cheng, T. C. E. (2008). The impact of employee satisfaction on quality and profitability in high-contact service industries. Journal of $\mathrm{Op}$ erations Management, 26(5), 651-668. https://doi. org/10.1016/j.jom.2008.01.001

Yeh, C. Y., Chen, C.-M. \& Hu, J.-L. (2012). Business diversification in the hotel industry: A comparative advantage analysis. Tourism Economics. https://doi.org/10.5367/te.2012.0152

Zanin, L. M., da Cunha, D. T., de Rosso, V. V., Capriles, V. D. \& Stedefeldt, E. (2017). Knowledge, attitudes and practices of food handlers in food safety: An integrative review. Food Research International, 100, 53-62. 